\title{
Myoglobin and creatine kinase in acute myocardial infarction
}

\author{
J M McCOMB, E A McMASTER, G MAcKENZIE, A A J ADGEY \\ From the Regional Medical Cardiology Centre, Royal Victoria Hospital, Belfast, Northern Ireland
}

SUMMARY Serum myoglobin concentration and creatine kinase activity were measured serially in 70 consecutive patients presenting within four hours of the onset of symptoms of suspected acute myocardial infarction. Of 36 patients with definite or possible myocardial infarction (WHO criteria), the serum myoglobin concentration was raised $(>85 \mu \mathrm{g} / \mathrm{l})$ one hour after the onset of symptoms in $25 \%$ and at four hours in $89 \%$. Creatine kinase activity was raised $(>140 \mathrm{U} / 1)$ one hour after the onset in $25 \%$ and at four hours in only $56 \%$. Within 12 hours of the onset of symptoms the myoglobin concentration reached a peak in $83 \%$ and the creatine kinase a peak in only $14 \%$. Within 36 hours the myoglobin concentration fell to normal values in $67 \%$ while creatine kinase activity fell to normal values in only $3 \%$. Four hours after the onset of symptoms the serum myoglobin concentration distinguished easily those patients with myocardial infarction from those without, whereas when creatine kinase values were used the sensitivity was poor but the specificity high.

From the combined results of the two studies and using a single measurement of serum myoglobin concentration at six hours from the onset of symptoms to predict the diagnosis in 114 patients with suspected infarction, the sensitivity was $93 \%$ and specificity $89 \%$.

Kiss and Reinhart ${ }^{1}$ first reported abnormal serum concentrations of myoglobin 10 to 12 hours after acute myocardial infarction. Since then, others have confirmed that most patients with acute myocardial infarction have a raised serum myoglobin concentration shortly after admission to hospital. ${ }^{2-5}$ Sylvén, using data from $\mathbf{4 0}$ patients admitted within six hours of the onset of symptoms of infarction, estimated that $20 \%$ would have raised serum myoglobin concentrations one hour after the onset of symptoms. ${ }^{6}$

Using a mobile coronary care unit we are able to assess patients at an earlier stage after myocardial infarction. In this study we compared the serum myoglobin concentration with the serum creatine kinase activity measured from blood samples collected during the very early hours of infarction and from the one collected at six hours after the onset of symptoms and compared the sensitivity and specificity for both myoglobin and creatine kinase.

\section{Patients and methods}

This study was carried out in two parts.

Requests for reprints to Dr A A J Adgey, Regional Medical Cardiology Centre, Royal Victoria Hospital, Belfast BT12 6BA, Northern Ireland.

Accepted for publication 6 September 1983
PART 1

Seventy consecutive patients with symptoms suggesting acute myocardial infarction-that is, typical distribution of chest pain with or without electrocardiographic changes-and presenting to a mobile and hospital coronary care unit within four hours of the onset of symptoms were studied. Blood samples were obtained at the time of presentation and at two hourly intervals for 48 hours using an indwelling cannula. Using an automated colorimetric technique serum creatine kinase activity was measured in the refrigerated serum. ${ }^{7}$ Serum myoglobin concentration was measured in the frozen serum using a radioimmunoassay (Nuclear Medical Systems). The diagnosis of myocardial infarction was made in each patient according to World Health Organisation criteria.$^{8}$ Intramuscular injections were avoided, but otherwise all patients received routine care.

\section{PART 2}

Fifty seven consecutive patients presenting within six hours of the onset of symptoms suggesting acute myocardial infarction were studied. Patients who had been resuscitated by cardioversion before entry were excluded. A single blood sample was taken six hours after the onset of symptoms. Concentrations of myoglobin and measurements of creatine kinase activity 


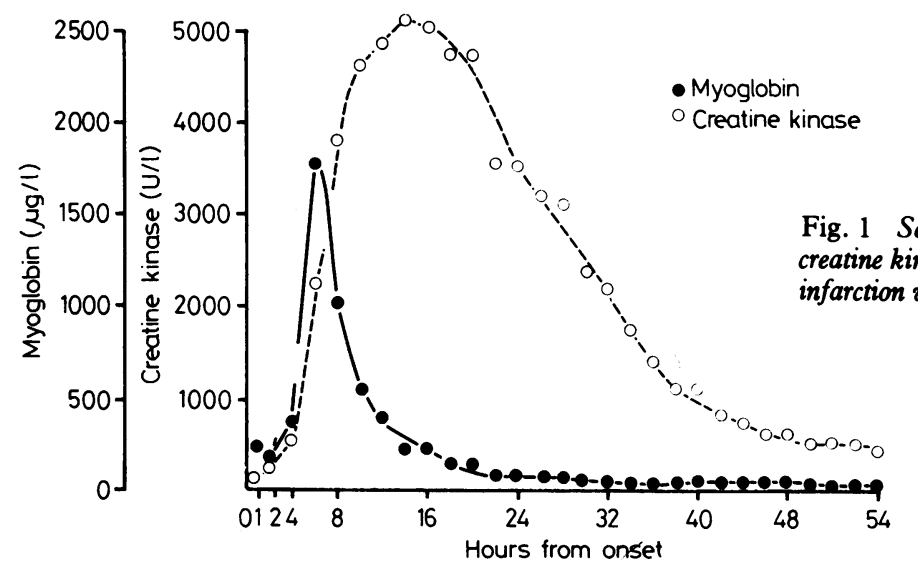

were determined and the diagnosis in each patient made according to the World Health Organisation criteria. $^{8}$

\section{Results}

\section{PART 1}

In 46 of the 70 patients an acute myocardial infarction was either definite or possible. ${ }^{8}$ Ten patients were excluded from the analysis, of whom eight presented in cardiac arrest from which they were resuscitated, one developed ventricular fibrillation two hours after presentation, and one had had a thoracotomy.

The serum myoglobin concentration was raised (>85 $\mu \mathrm{g} / \mathrm{l}$ ) during the sampling period in the remaining 36 patients. It was raised within the first

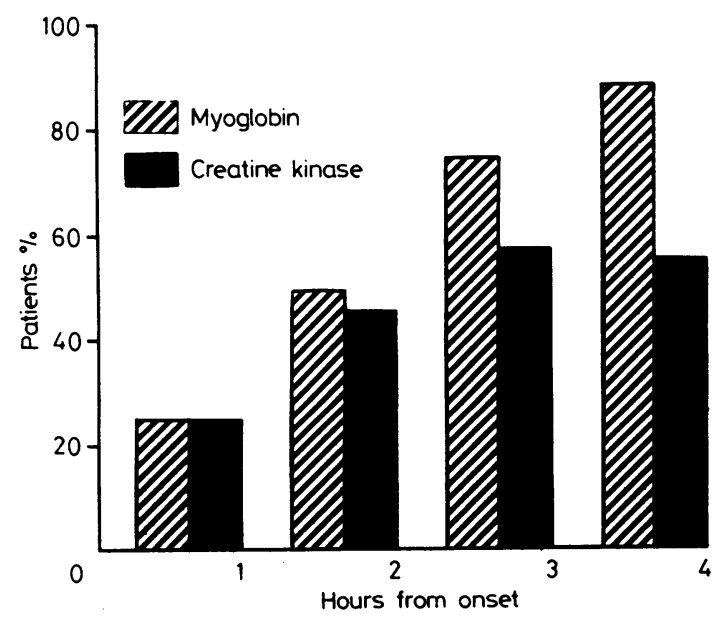

Fig. 2 Percentage of patients with raised serum myoglobin concentration and creatine kinase activity at each time interval from the onset of symptoms. hour in one of the four patients (Figs. 1 and 2) (range 28-235 (mean 94.75 \pm 95.58$) \mu \mathrm{g} / \mathrm{l}$ ). Creatine kinase activity $(>140 \mathrm{U} / \mathrm{l})$ was also raised in one of the four patients (range 56-228 (mean 128.5 $\pm 74 \cdot 14$ ) U/1) (Fig. 2). The serum myoglobin concentration was raised within two hours of the onset in 13 of the 26 patients (50\%) (range $9-660$ (mean $194 \pm 241) \mu \mathrm{g} / \mathrm{l}$ ), and serum creatine kinase was raised in 12 (mean $189 \pm 173$ (range 25-866) U/l). Four hours after the onset of symptoms the serum myoglobin concentration was raised in 32 of the $36(89 \%)$ (range 10-2220 (mean $331 \pm 401) \mu \mathrm{g} / \mathrm{l}$ ) and the serum creatine kinase activity in $20(56 \%$ ) (range $11-1569$ (mean 268 255 ) U/l). Six hours after the onset of symptoms the serum myoglobin concentration was raised in $33(92 \%)$ (range 50 1735 (mean 505 \pm 447$) \mu \mathrm{g} / \mathrm{l}$ ) and the serum creatine kinase activity in 30 (83\%) (range 23-2276 (mean $519 \pm 532) \mathrm{U} / \mathrm{l})$. The serum myoglobin concentration was normal in three patients and creatine kinase activity in six patients six hours after the onset of symptoms.

Fig. 3 compares the mean serum myoglobin concentration and creatine kinase activity in relation to time from the onset of symptoms in all 36 patients. Myoglobin concentrations rise and peak earlier and return to normal values earlier than creatine kinase activity. The peak serum myoglobin concentration (mean $797 \pm 597 \mu \mathrm{g} / 1$ ) had occurred within nine hours of the onset of symptoms in 24 of $36(67 \%)$ patients and within 12 hours in 30 (83\%) (Fig. 4). The peak serum creatine kinase activity (mean 2046 $\pm 1413 \mathrm{U} / \mathrm{l}$ ) occurred within 12 hours in only five of 36 (14\%) patients. There were multiple myoglobin peaks during the 48 hours in 16 of the 36 patients. The maximum number of distinct peaks observed was four. Nine of the 16 patients with multiple myoglobin peaks also had multiple creatine kinase peaks. Only one patient with multiple peaks had a recurrence of chest pain during the study period. The serum myo- 


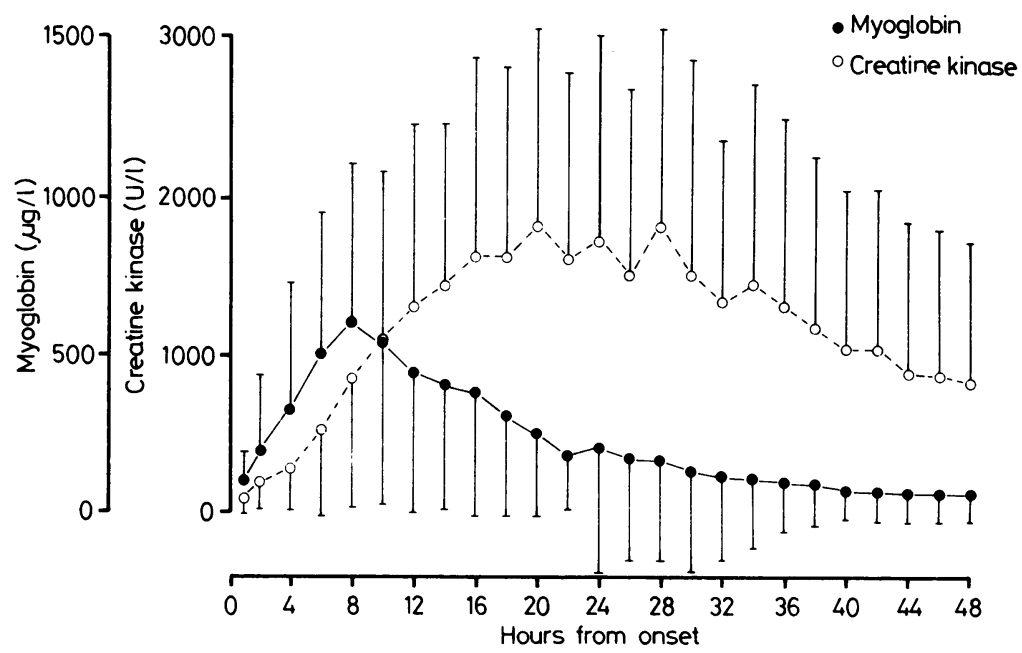

Fig. 3 Serial measurements of myoglobin concentration and creatine kinase activity in 36 patients with acute myocardial infarction. Results are means $\pm S D$.

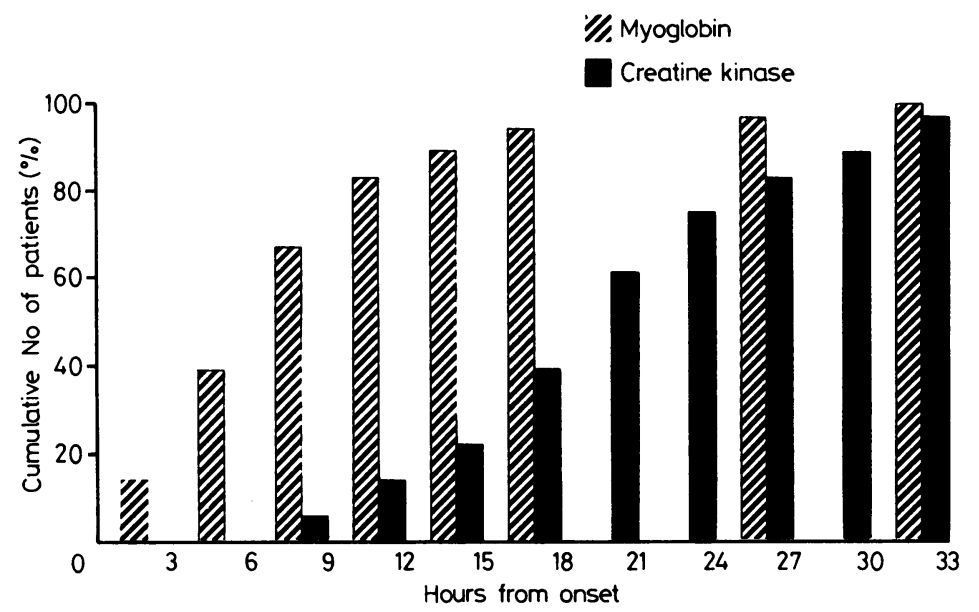

Fig. 4 Time from onset of symptoms to peak myoglobin concentration and peak creatine kinase activity.

globin concentration returned to normal within 24 hours of the onset of symptoms in 14 of the $36(39 \%)$ and within 36 hours in $24(67 \%)$ patients (Fig. 5). The serum creatine kinase activity returned to normal values within 36 hours in only one (3\%) and within 48 hours in five patients. The serum myoglobin concentration was still abnormal after 48 hours in seven patients, and the serum creatine kinase activity still raised in 31 .

Regression analysis was used to determine whether or not any factor other than myocardial infarction affected the serum myoglobin concentration. Age, sex, weight, and blood urea concentration were shown to have no effect. One patient had left ventricular failure without myocardial infarction, and this was associated with a raised serum myoglobin concentraion. Creatine kinase activity in this patient was normal.

Of the remaining 24 of the 70 patients without definite or possible myocardial infarction, ${ }^{8} 14$ had 


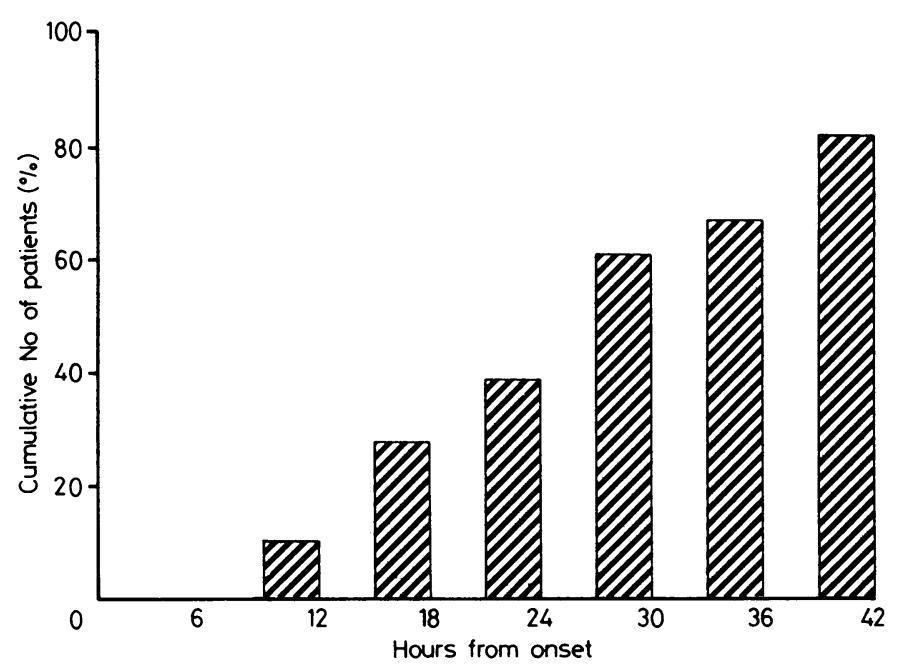

Fig. 5 Time to return to normal values of myoglobin.

acute coronary insufficiency with electrocardiographic changes during pain, five had chest pain (? diagnosis), one had chest pain with left ventricular failure, one had a pneumothorax, one had ventricular fibrillation following complete heart block, and two were resuscitated from collapse without cardioversion. At six hours from the onset in these patients the serum myoglobin concentration was raised in two and creatine kinase activity was raised in one.

Four hours after the onset of symptoms the sensitivity and specificity for measurements of myoglobin and creatine kinase were calculated for the 36 patients with myocardial infarction and the 21 without myocardial infarction (excluding three resuscitated patients) (Table 1). For myoglobin the sensitivity was $\mathbf{9 2 \%}$ and the specificity $95 \%$ and for creatine kinase the figures were $56 \%$ and $100 \%$ respectively.

\section{PART 2}

Thirty two of the 57 patients had had an acute myocardial infarction (definite or possible) ${ }^{8}$ six hours after the onset of symptoms. The serum myoglobin concentration was raised in 34 patients, 30 of whom had had an infarction (Table 2). The four patients without infarction in whom the serum myoglobin concentration was raised all had left ventricular failure. The serum creatine kinase activity was raised in 29,26 of whom had had an infarction.

When the results of both studies (parts 1 and 2) are combined, of 127 patients 13 were excluded from assessment as 10 were resuscitated from ventricular fibrillation, two from bradyarrhythmia without cardioversion, and one had had a pneumonectomy. Thus serum myoglobin concentration and creatine kinase
Table 1 Serum myoglobin concentrations and creatine kinase activity four hours from onset of symptoms in 36 patients with acute myocardial infarction and in 21 without (part 1). Figures are numbers of patients

\begin{tabular}{llc}
\hline & $\begin{array}{l}\text { Acute } \\
\text { myocardial } \\
\text { infarction }\end{array}$ & Other \\
\hline Serum myoglobin concentration & 33 & 1 \\
$\quad$ Raised & 3 & 20 \\
$\quad$ Normal & 20 & 0 \\
Serum creatine kinase activityt & 16 & 21 \\
Raised & & \\
\hline
\end{tabular}

$\star$ Sensitivity $92 \%$; specificity $95 \%$.

†Sensitivity $56 \%$; specificity $100 \%$.

Table 2 Serum myoglobin concentrations and creatine kinase activity in 57 patients with suspected acute myocardial infarction six hours after the onset of symptoms (part 2). Figures are numbers of patients

\begin{tabular}{llr}
\hline & $\begin{array}{l}\text { Acute } \\
\text { myocardial } \\
\text { infarction }\end{array}$ & Other \\
\hline Serum myoglobin concentration & 30 & 4 \\
$\quad$ Raised & 2 & 21 \\
Normal & 26 & 3 \\
Serum creatine kinase activity & 6 & 22 \\
$\quad$ Raised & 6 & \\
Normal & & \\
\hline
\end{tabular}

activity were measured in 114 patients with suspected infarction. Sixty eight of these patients were subsequently found to have had an infarction (definite or possible) ${ }^{8}$ (Table 3 ). The serum myoglobin concentration was raised in $63(93 \%)$ of these patients six hours 
Table 3 Serum myoglobin concentrations and creatine kinase activity in 114 patients with suspected myocardial infarction six hours from the onset of symptoms (combined results). Figures are numbers of patients

\begin{tabular}{llr}
\hline & $\begin{array}{l}\text { Acute } \\
\text { myocardial } \\
\text { infarction }\end{array}$ & Other \\
\hline Serum myoglobin concentration & & \\
$\quad$ Raised & 63 & 5 \\
$\quad$ Normal & 5 & 41 \\
Serum creatine kinase activity & 56 & 3 \\
$\quad$ Raised & 12 & 43 \\
\hline Normal & 12 & \\
\hline
\end{tabular}

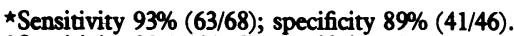

†Sensitivity $82 \%$ (56/68); specificity $93 \%$ (43/46).

after the onset of symptoms and the serum creatine kinase activity was raised in $56(82 \%)$. All five patients without infarction in whom the myoglobin concentration was raised at six hours from the onset of symptoms had left ventricular failure. Using a single serum myoglobin concentration at six hours to predict the diagnosis, the sensitivity was 63 out of $68(93 \%)$ and the specificity 41 out of $46(89 \%)$. Using a single value for creatine kinase activity sensitivity was $82 \%$ and specificity $93 \%$.

\section{Discussion}

The first part of this study showed that the serum myoglobin concentration rises in most patients within four hours of the onset of symptoms of acute myocardial infarction and in almost all within six hours, whereas the serum creatine kinase activity was slower to rise within the early hours of infarction. It also shows the earlier peak and the earlier return to normal values of the serum myoglobin concentration compared with those of the serum creatine kinase activity after acute infarction. Thus if chest pain is recurrent the serum myoglobin concentration may be an indicator of further necrosis.

The second part of the study allowed prospective verification of a single measurement of serum myoglobin concentration six hours after the onset of infarction, when notable sensitivity was achieved at this time. It is difficult to know when cardiac necrosis starts. Experimental occlusion of a coronary artery in dogs does not cause immediate infarction, cell death being detectable only 20 minutes after the occlusion. ${ }^{9}$ After coronary occlusion in dogs, myoglobin appears in plasma $1.6 \pm 0.4$ hours after the occlusion peaks at six hours, and it disappears at 10 hours. ${ }^{1011}$ In man the time of the onset of coronary occlusion is not known, and measurements may be made only from the onset of symptoms. Myoglobin is partly degraded in the reticuloendothelial system but is also degraded in and excreted by the kidney. ${ }^{12-14}$ Impaired renal function can lead to delay in excretion of myoglobin and so in return of the serum myoglobin concentration to normal values. None of our patients had established renal failure, but the blood urea concentration rose in many with large infarctions within the first few days.

In patients with chest pain without infarction the serum myoglobin concentration has been raised in two of 44,2 eight of 18,15 and two of $53.1^{16}$ In the first part of this study of 24 patients without infarction only two had a raised myoglobin concentration at six hours from the onset of symptoms. Stone et al found no appreciable change in serum myoglobin concentration in dogs with temporary coronary occlusion (15 minutes) followed by reflow. ${ }^{11}$ This time period is unlikeiy to produce cardiac necrosis. This seems to imply that any release of myoglobin denotes necrosis. Nevertheless, myoglobin has the same disadvantages as creatine kinase in terms of lack of specificity. Resuscitation, skeletal muscle trauma, and intramuscular injections are the usual causes of false positive results. The serum myoglobin concentration is usually raised after cardioversion, ${ }^{17-19}$ but some workers have reported it to be normal. ${ }^{16}$ The rise in serum myoglobin concentration after a single intramuscular injection is not pronounced and occurs in only about half the patients. ${ }^{20}$ This study showed that left ventricular failure has an effect on the serum myoglobin concentration independent of that of acute myocardial infarction. Stone et al and Oxley et al have both reported a raised serum myoglobin concentration in one patient with congestive heart failure and no infarction ${ }^{219}$; otherwise most workers have found serum myoglobin concentrations within the normal range in these patients. ${ }^{2} 162122$

It is usual to measure the serum creatine kinase, aspartate transaminase, and lactic dehydrogenase activity on at least three successive days after the onset of symptoms. Comparison of a single myoglobin concentration with nine or more measurements of enzyme activity over several days is inappropriate, and we do not suggest that a single myoglobin concentration six hours after the onset of pain replaces the currently accepted criteria. We do, however, consider that a single myoglobin concentration measured six hours after the onset of symptoms is of notable value in the early confirmation of the diagnosis of infarction.

\section{References}

1 Kiss A, Reinhart W. Ueber den Nachweis des Myoglobins im Serum und im Harn nach Herzinfarkt. Wien Klin Wochenschr 1956; 68: 154-5. 
2 Stone MJ, Waterman MR, Harimoto D, et al. Serum myoglobin level as diagnostic test in patients with acute myocardial infarction. Br Heart f 1977; 39: 375-80.

3 Sylven C, Bendz R. Myoglobin, creatine kinase and its isoenzyme MB in serum after acute myocardial infarction. Eur f Cardiol 1978; 8: 515-21.

4 Kaiser H, Spaar U, Sold G, Wolfrum DI, Kreuzer H. Radioimmunologische Bestimmung von HumanMyoglobin in der Diagnostik des akuten Myokardinfarkts. Klin Wochenschr 1979; 57: 225-35.

5 Freeman AP, Fatches KR, Carter IW, Cloonan MJ, Wilcken DEL. Comparison of serum myoglobin and creatine kinase $M B$ isoenzyme in early diagnosis of acute myocardial infarction. Br Heart f 1981; 45: 389-92.

6 Sylvén C. Release of myoglobin and creatine-kinase into serum following acute myocardial infarction. Eur $\mathcal{F}$ Cardiol 1979; 9: 483-91.

7 Automation in analytical chemistry. Technicon symposia 1966. Vol 1. New York: Mediad Incorporated, 1967.

8 World Health Organisation. WHO criteria for the diagnosis of acute myocardial infarction. Proposal for the multinational monitoring of trends and determinants in cardiovascular disease. Geneva: Cardiovascular Diseases Unit of WHO, 1981.

9 Jennings RB, Sommers HM, Smyth GA, Flack HA, Linn H. Myocardial necrosis induced by temporary occlusion of a coronary artery in the dog. Arch Pathol 1960; 70: 68-78.

10 Lwebuga-Mukasa JS, Libby P, Bloor CM, Maroko P. The evaluation of serum myoglobin following experimental coronary occlusion [Abstract]. Circulation 1973; 47 and 48 (suppl II): IV-129.

11 Stone MJ, Waterman MR, Poliner LR, Templeton GH, Buja LM, Willerson JT. Myoglobinemia is an early and quantitative index of acute myocardial infarction. Angiology 1978; 29: 386-92.

12 Amako T, Koga J, Kobayashi A, Urakado S, Tokunaga $\mathrm{J}$. Experimental investigation of the metabolism of myo- globin. Kyushu f Med Sci 1963; 14: 277-87.

13 Sylven C. The kinetics of myoglobin in old volunteers and in patients with acute myocardial infarction. Scand $\mathcal{F}$ Clin Lab Invest 1978; 38: 561-5.

14 Tommaso CL, Salzeider K, Arif M, Klutz W. Serial myoglobin vs. CPK analysis as an indicator of uncomplicated myocardial infarction size and its use in assessing early infarct extension. Am Heart f 1980; 99: 149-54.

15 Klocke FJ, Visco JP, Reichlin M. Myoglobinemia as an index of myocardial infarction and/or ischemia[Abstract]. Circulation 1976; 53 and 54 (suppl II): II-29.

16 Gilkeson G, Stone MJ, Waterman M, et al. Detection of myoglobin by radioimmunoassay in human sera: its usefulness and limitations as an emergency room screening test for acute myocardial infarction. Am Heart $\mathcal{f}$ 1978; 95: 70-7.

17 Rosano TG, Sanders LA, Johnson ES, Kenny MA, Clayson KJ, Strandjord PE. Myoglobin concentrations and muscle-enzyme activities in serum after myocardial infarction and cardiac arrhythmia. Clin Chem 1977; 23: 868-70.

18 Kubasik NP, Guiney W, Warren K, D'Souza JP, Sine HE, Brody B. Radioimmunoassay of serum myoglobin: evaluation and modification of a commercial kit and assessment of its usefulness for detecting acute myocardial infarction. Clin Chem 1978; 24: 2047-9.

19 Oxley DK, Bolton MR, Shaeffer CW. Myoglobin in myocardial infarction. Am f Clin Pathol 1979; 72: 13741.

$20 \mathrm{McComb}$ JM, McMaster EA. Serum myoglobin after cardiac catheterisation. Br Heart f 1982; 47: 353-6.

21 Stone MJ, Willerson JT, Gomez-Sanchez CE, Waterman MR. Radioimmunoassay of myoglobin in human serum. f Clin Invest 1975; 56: 1334-9.

22 Stone MJ, Waterman MR, Willson NR, et al. Radioimmunoassay of serum myoglobin in the diagnosis of acute myocardial infarction in patients [Abstract]. Circulation 1976; 54 (suppl II): II-29. 